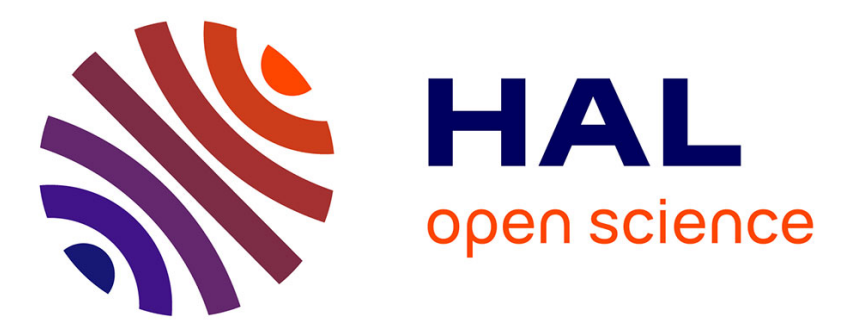

\title{
Detection of Nosema apis and N. ceranae in honeybee bottom scraps and frass in naturally infected hives
}

\author{
Tanya Copley, Pierre Giovenazzo, Suha Jabaji
}

\section{To cite this version:}

Tanya Copley, Pierre Giovenazzo, Suha Jabaji. Detection of Nosema apis and N. ceranae in honeybee bottom scraps and frass in naturally infected hives. Apidologie, 2012, 43 (6), pp.753-760. 10.1007/s13592-012-0147-8 . hal-01003668

\section{HAL Id: hal-01003668 \\ https://hal.science/hal-01003668}

Submitted on 1 Jan 2012

HAL is a multi-disciplinary open access archive for the deposit and dissemination of scientific research documents, whether they are published or not. The documents may come from teaching and research institutions in France or abroad, or from public or private research centers.
L'archive ouverte pluridisciplinaire $\mathbf{H A L}$, est destinée au dépôt et à la diffusion de documents scientifiques de niveau recherche, publiés ou non, émanant des établissements d'enseignement et de recherche français ou étrangers, des laboratoires publics ou privés. 


\title{
Detection of Nosema apis and $N$. ceranae in honeybee bottom scraps and frass in naturally infected hives
}

\author{
Tanya R. Copley ${ }^{1}$, Pierre Giovenazzo ${ }^{2}$, Suha H. JABAлI ${ }^{1}$ \\ ${ }^{1}$ Plant Science Department, McGill University, 21,111 Lakeshore, Ste-Anne-de-Bellevue, QC, Canada H9X 3V2 \\ ${ }^{2}$ Department of Biology, Laval University, Quebec, QC, Canada G1V 0A6
}

Received 22 August 2011 - Revised 21 April 2012 - Accepted 24 May 2012

\begin{abstract}
Current sampling methods for identification of honeybee microsporidians (Nosema apis and Nosema ceranae) involve killing adult honeybees. The current study monitored the presence of $N$. apis and N. ceranae in honeybee frass and bottom scraps collected from six hives located in Deschambault, Quebec, Canada, from 2009 to 2010. Infection rates of $N$. ceranae and $N$. apis were quantified using duplex qPCR enabling the simultaneous detection of single and co-infections of the two species. Screening of all sample types revealed a greater presence of $N$. ceranae. qPCR infection levels for both Nosema species in bees and bottom scraps were correlated and showed a significant correlation $(P<0.001)$ between infection rates of $N$. apis, while no significant correlative relationship $(P=0.1037)$ was observed between those of $N$. ceranae. This study has demonstrated that Nosema spp. can be detected and reliably quantified in bottom scraps and frass of bee hives using qPCR diagnostic assays, and additionally, these techniques are not detrimental to the hive health, faster, and as reliable as sampling bees from within the colony when combined with qPCR diagnostic tests.
\end{abstract}

Nosema ceranae / Nosema apis / disease indicator / bottom scraps / frass

\section{INTRODUCTION}

Nosema disease of the European honeybee, Apis mellifera L., is caused by two described unicellular microsporidian species Nosema apis Zander and Nosema ceranae Fries (Fries 2010; Chen and Huang 2010). The spores of both parasites are ingested by honeybees through the consumption of contaminated food sources such as water, pollen, or honey, or when cleaning the hive and removing contaminated frass or dead bees (Fries and Camazine 2001; Higes et al. 2008a). Due to the increasing number of hives that are dwindling, it is crucial not only to fully understand Nosemosis, but also limit the amount

Corresponding author: S.H. Jabaji, suha.jabaji@mcgill.ca

Manuscript editor: Yves Le Conte of damage done to the hives when detecting diseases. Hives infected with $N$. apis are known to increase dysentery within and around the hives, while $N$. ceranae appears to cause less dysentery than N. apis (Bailey 1968; Fries et al. 2006; Fries 2010). If dysentery is present during infection with both Nosema species, and spores are defecated out during this process, then spores may be present within the hive and in the faecal dropping (frass) resulting in a potentially new source of inoculum for horizontal transmission of both Nosema species. Bailey (1955) provided some evidence that faeces of $N$. apis can represent a reservoir of the disease and may initiate an outbreak in newly emerged bees. Another potential source of Nosemosis is the corbicular pollen suggesting that pollen may be a source of infection within hives (Higes et al. 2008a). Pollen is found throughout the hive, and 
is often dropped within the hive and mixed with other debris found on the bottom board of a hive suggesting that this debris (bottom scraps) may also be a potential source of Nosema species infections. Despite the global prevalence of Nosema species, little is known about the detection and monthly distribution of Nosema species in bottom scraps and frass and is the subject of this study.

One of the most sensitive and efficient PCR methods that has been developed to differentiate and quantify Nosema species in honeybees in a single reaction is multiplex quantitative real-time PCR (qPCR). This method amplifies the same 16SSU rDNA regions allowing for the quantification of $N$. apis and $N$. ceranae simultaneously in a single reaction (Chen et al. 2009; Copley and Jabaji 2012). Therefore, the major motivation for this study was to apply a duplex qPCR assay that simultaneously detects both $N$. apis and $N$. ceranae and to provide preliminary evidence that the bottom scraps of hives and frass from honeybees contain Nosema species and may be useful indicators of the presence of Nosemosis within hives. A secondary goal was the application of the assay to measure the infection levels of both Nosema species over a period of 8 months and attempt to correlate these levels to those found within the intestines of honeybees of the same hives.

\section{MATERIALS AND METHODS}

\subsection{Sample collection}

Four hives were established from hive material including screened bottom boards previously sterilized with ethylene oxide. Hives were placed at the Centre de Recherche en Sciences Animales de Deschambault (CRSAD), Deschambault $\left(46.6734^{\circ} \mathrm{N}, 71.9169^{\circ} \mathrm{W}\right)$, Quebec, Canada in 2008. Preliminary screenings using conventional PCR from samples collected in 2008 indicated that all hives were infected with at least one Nosema species. A total of 32 collections, each consisting of 100 worker bees were sampled from the side frames of the top super of the four on a monthly basis during eight of the active months from July 2009 to July 2010. Equally, 32 bottom scrap samples were collected from the same hives at the same time points as the bee samples by scraping the bottom board with the hive tool and collecting the entire debris that accumulated between sampling dates into a sterile plastic bag and removing any dead bees. Hives were overwintered in a common environmentally controlled room $\left(3-5{ }^{\circ} \mathrm{C}\right.$ and $\left.30-40 \% \mathrm{RH}\right)$ from November 2009 to April 2010, during which no collections of bees or bottom scraps were made. On April 14, 2010, hives were placed outdoors with Shark Skin Grade Whatman filter papers $(53.34 \times 46.0 \mathrm{~cm})$ on top of each of the four hives for $2 \mathrm{~h}$ to collect frass from bees flying over the hives. To increase the sample size for the collection of frass two additional hives located at the same apiary but outside of the study group also had filter papers placed on their outer hive tops $(n=6)$. At the same time as the frass collection approximately 100 worker bees were collected from all six hives $(n=6)$. All samples were kept at $-20^{\circ} \mathrm{C}$ until further use.

\subsection{Sample preparation and DNA extraction}

For each honey bee collection, the midgut and hindgut (hereafter referred to as intestines) of 30 bees were dissected, pooled, and ground with a mortar and pestle in $30 \mathrm{~mL}$ of sterile $\mathrm{ddH}_{2} \mathrm{O}$. For the frass samples, 60 droppings per filter paper were cut from the filter paper using a standard hole puncher $(6 \mathrm{~mm})$, and soaked in sterile $\mathrm{ddH}_{2} \mathrm{O}$ until all the frass had dissolved. All samples were filtered and the total number of Nosema spores were estimated according to the method of Copley and Jabaji (2012). Filtered samples were then pelleted for $10 \mathrm{~min}$ at $8,500 \times g$ and the pellet used for DNA extraction. Bottom scraps were ground to a fine powder using liquid nitrogen and $100 \mathrm{mg}$ was used for DNA extraction. DNA from all sample types was extracted using the DNeasy Mini Plant Kit (QIAGEN, Mississauga, ON, Cat no. 69104) following the manufacturer's protocols and then was electrophoresed for DNA quality.

\subsection{Conventional and duplex quantitative real-time PCR}

For conventional PCR, DNA extracted from all samples was tested with already published primers sets specific to $N$. ceranae, $N$. apis, and 
A. mellifera actin in separate PCR reactions (Martín-Hernández et al. 2007). PCR reactions were run according Copley and Jabaji (2012) with either $250 \mathrm{ng}$ intestinal DNA or 25-ng bottom scrap or frass DNA per reaction in a total volume of $12.5 \mu \mathrm{L}$. All primer sets were run with a positive control containing templatespecific plasmids and a negative control containing no template DNA. Visualization of products was carried out according to Copley and Jabaji (2012).

For duplex qPCR, all samples were tested for the presence of $N$. ceranae, N. apis, and $A$. mellifera actin using duplex qRT-PCR using the Stratagene MxPro 3005. Primers and probes for $N$. ceranae (Nceranae; GenBank accession no. DQ486027), N. apis (Napis; GenBank accession no. DQ486027), and A. mellifera $\beta$-actin (GenBank accession no. AB023025) as the normalizer gene, resulting in amplified products of 250,
269, and $181 \mathrm{bp}$, respectively, were synthesized by Integrated DNA Technologies (San Diego, CA) for duplex qPCR. Fluorophore probe labelling for all primers and standard curve preparation was performed as previously described by Copley and Jabaji (2012) to allow for the amplification of all amplicons simultaneously in a duplex qPCR reaction.

Each duplex amplification mixture were run using the conditions described in Copley and Jabaji (2012) with either $250 \mathrm{ng}$ bee intestinal DNA or $25 \mathrm{ng}$ bottom scrap or frass DNA in a total volume of $25 \mu \mathrm{L}$. A. mellifera actin was amplified in a separate mixture using the same conditions. Actin and Nosema species qPCR reactions were run on the same plate for all samples. Standard curves ranging from $10^{2}$ to $10^{9}$ copies of template-specific plasmids per reaction and no template controls were run with each plate (Copley and Jabaji 2012). All samples were

a) Genomic DNA from bee intestines, bottom scraps and frass

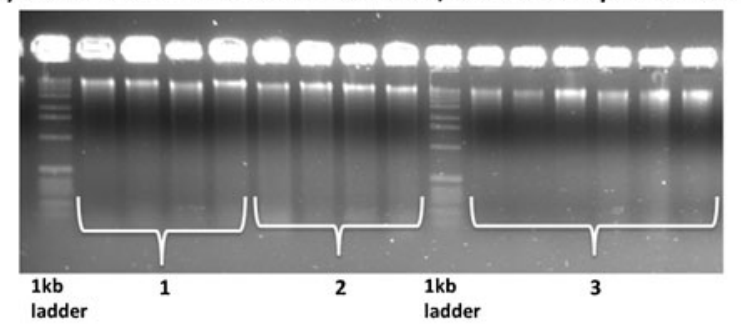

b) PCR amplification of genomic DNA

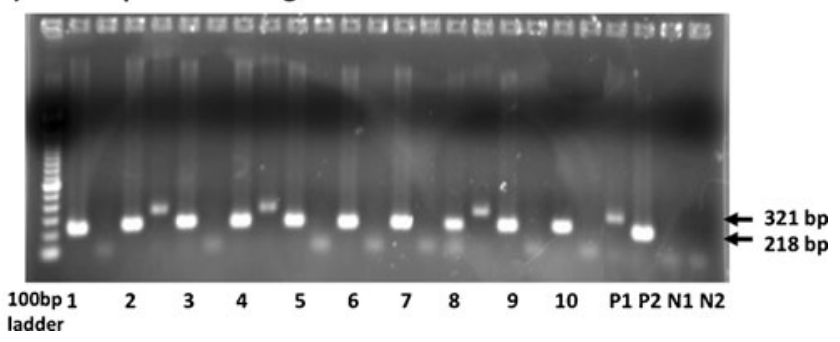

Figure 1. Gel electrophoresis of DNA extracted from bee intestines, bottom scraps, and frass. (a) and amplified using species-specific primers (b). a $100 \mathrm{ng}$ DNA from bee intestines (1), bottom scraps (2), and frass (3). b PCR amplification of bee intestinal (1-4), bottom scraps (5-8), and frass (9-10) DNA using primers specific to $N$. ceranae $(218 \mathrm{bp})$ and $N$. apis $(321 \mathrm{bp})$ on a $1.5 \%$ agarose gel electrophoresis. For each sample, $N$. ceranae then $N$. apis PCR products were loaded in neighbouring lanes. All samples were positive for $N$. ceranae, while samples 2, 4, and 8 showed co-infections. $N 1$ indicates the negative control for $N$. apis, $N 2$ for $N$. ceranae. P1 indicates the positive control for $N$. apis, $P 2$ for $N$. ceranae. The size of the PCR fragment is indicated on the right. 
performed in triplicate. Amplification results were expressed as the threshold cycle $\left(C_{T}\right)$ value, and converted to copy numbers by plotting the $C_{T}$ values against the standard curve. To ensure that sensitivity was maintained during the duplex qPCR, reactions containing $10^{9}$ copies of $N$. apis in combination with $10^{2}$ copies of $N$. ceranae and vice versa were performed ensuring that high amounts of one species did not inhibit the amplification of lower titers of the other species.

\subsection{Statistical analysis}

The coefficient of correlation $(r)$ values were calculated for each Nosema species to determine how well the amount of infection in the bee intestines correlated to the amount of infection found in bottom scraps from the same hive for the same month using the restricted maximum likelihood method (JMP 8, SAS Institute, Inc., NC). Copy numbers were log transformed and outliers were determined using the Jacknife distance method and removed (JMP 8, SAS Institute, Inc., NC). Principle component analysis (PCA) was done with all bottom scrap and bee samples using SIMCA-P ${ }^{+} 12.0$ software (Umetrics, MKS Instruments Inc., Sweden) to validate the correlation analyses. Data from frass samples were presented as a scatter plot against bee samples. No statistical analyses were done on these samples due to the small sample size.

\section{RESULTS}

DNA extracted from each sample collected consisting of 30 bee intestines, 60 frass droppings, or $100 \mathrm{mg}$ bottom scraps yielded high quality DNA (Figure 1a) that was successfully amplified using the 16SSU rDNA speciesspecific primers of $N$. ceranae and $N$. apis, with the expected product size of 219 and $321 \mathrm{bp}$, respectively (Figure 1b). The reference gene encoding for $\beta$-actin was present in all samples, demonstrating that Nosema-negative

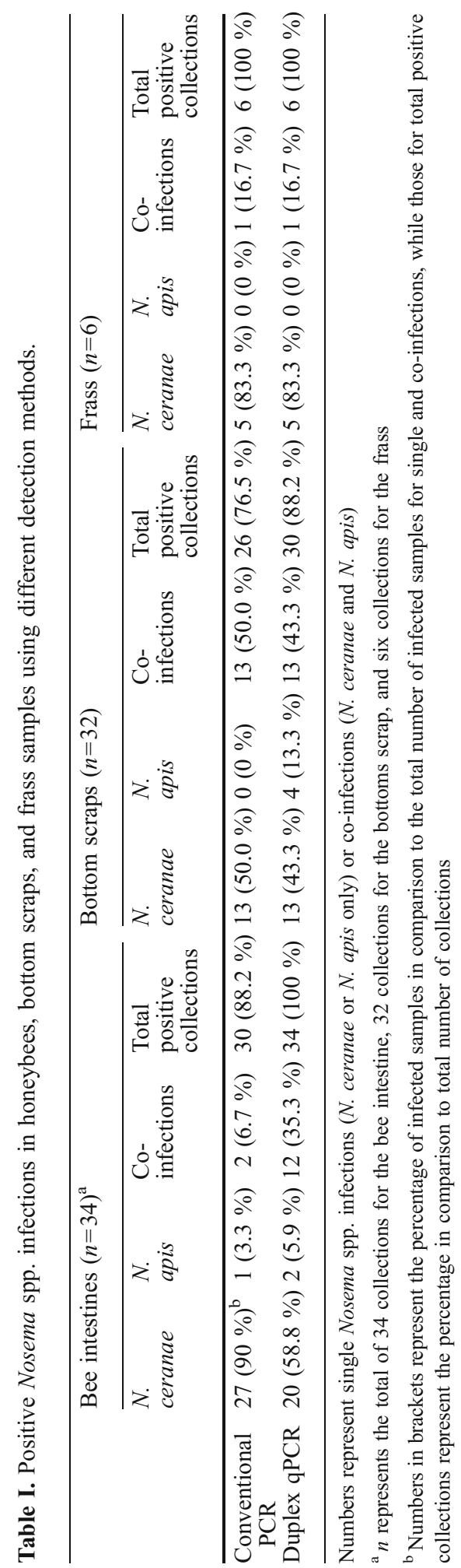


collections were amplifiable and represent true negatives (data not shown).

Compared to conventional PCR assays (Table I), the number of $N$. apis-positive samples or samples that had co-infections was higher when using duplex qPCR. $N$. ceranae was the more prevalent pathogen in all sample types, being detected during every collection month. All 34 bee collections tested positive for at least one Nosema species: $58.8 \%$ were infected with only $N$. ceranae, $5.9 \%$ with only $N$. apis, and $35.3 \%$ were co-infected (Table I) with detection limits as low as 70 or 100 copies/reaction for $N$. apis and $N$. ceranae, respectively. A percentage of $43.3 \%$ of bottom scraps samples detected only $N$. ceranae, $13.3 \%$ being infected with only $N$. apis, and $43.3 \%$ having co-infections (Table I). Positive samples were identical in conventional PCR and qPCR for the frass collections with five of the six collections testing positive for $N$. ceranae, and the remaining sample having a co-infection (Table I).

The infection rates for $N$. ceranae in bee intestines and frass samples appear to have a strong relationship. No relationship could be established between the infection rates of $N$. apis in bees and frass as only one frass sample tested positive for $N$. apis, while all of the bee samples had detectable infections (Figure 2). A strong correlation was established between infection rates of bottom scraps and bee intestines for $N$. apis $(r=0.8697, P<0.0001, n=29)$, where as a moderate but insignificant correlation for $N$. ceranae ( $r=0.3403, P=0.1037, n=28$; Figure 3a, b) was found. PCA confirmed these correlations as the infections of $N$. apis in bottom scraps and bees were located very closely in the same quadrant, while those for $N$. ceranae were in different quadrants suggesting a weaker relationship between the two infection levels (Figure 3c).

Monthly variation in infection levels in bee intestines were not significant $(P>0.05)$, however, the data shows similar patterns between bee intestines and bottom scraps (Figure 4). Generally, higher infection levels of both species occurred in the spring and early summer followed by decreased levels in late fall for both midgut and bottom scrap infections (Figure 4).
Interestingly, more DNA copies of $N$. ceranae were found in intestines compared to bottom scraps (Figure 4a) while the inverse was true for N. apis (Figure 4b).

\section{DISCUSSION}

Monitoring of Nosema species levels in bees and bottom scrap samples spanning a period of 8 months was successfully achieved using duplex qPCR assay. This provides simultaneous detection, differentiation, and quantification of nosemosis that otherwise cannot be accomplished by other current PCR assays (Higes et al. 2006; Klee et al. 2007; Traver and Fell 2011).

Our results show that levels of $N$. ceranae in the frass appear to be strongly influenced by the infection levels in the honeybee intestines

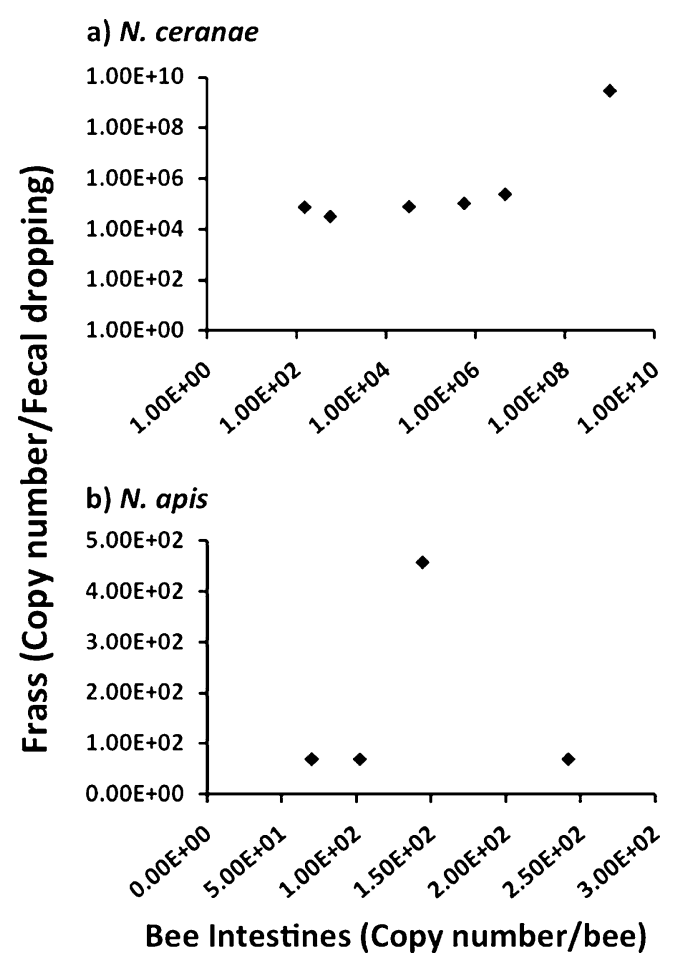

Figure 2. a Scatter plot of $N$. ceranae copy number in frass and bee intestines. b Scatter plot of N. apis copy number in frass and bee intestines. Axes are $\log _{10}$ transformed. Correlation analyses were not performed due to small sample size. 


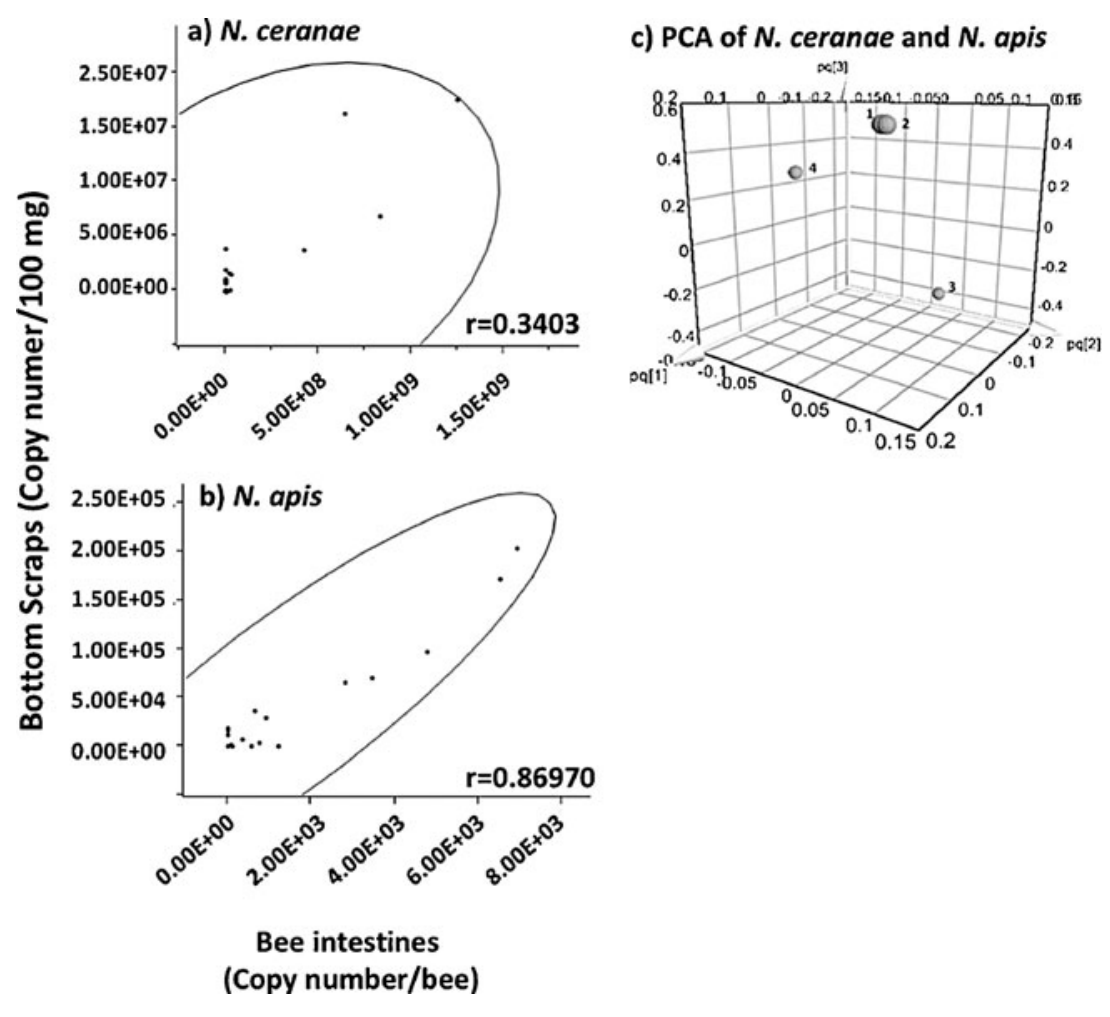

Figure 3. a Correlation analysis $(r=0.3403, P=0.1037, n=28)$ of $N$. ceranae copy number and $\mathbf{b} N$. apis $(r=$ $0.8697, P<0.0001, n=28$ ) copy number in bottom scraps and bee intestines Correlation analyses and Jacknife distances to remove outliers were done using JMP 8 (SAS Institute, Inc., NC). c Principle component analysis (PCA) of $N$. ceranae and $N$. apis copy number in bee intestines and bottom scrap samples. $1-N$. apis in bee intestines, $2-N$. apis in bottom scraps, 3-N. ceranae in bee intestines, and 4$N$. ceranae in bottom scraps. PCA analysis was done using SIMCA- $\mathrm{P}^{+} 12.0$ software (Umetrics, MKS Instruments Inc., Sweden).

despite the small sample size. Larger studies are required to determine if this relationship is significant. We recognize that the frass collection time was limited to a single sampling time, however, if this relationship holds true when multiple sampling is done over an extended period of time, it is plausible to suggest that sampling faecal matter may improve the sensitivity of the assay, and prove to be a quick, and non-detrimental method to detect $N$. ceranae in naturally infected beehives and apiaries.

In the case of $N$. apis, infections have been shown to have seasonal patterns (Bailey 1955; Martín-Hernández et al. 2007) and different pathology than $N$. ceranae. These differences may partly explain the lack of relationship between the bee intestinal infection levels and frass samples for $N$. apis. The frass samples collected showed little signs of dysentery supporting the idea that the selected monthly sampling time (i.e., April 2010) may not be ideal nor conducive to the release of $N$. apis spores into faecal droppings. Further studies are needed to clarify this issue. Interestingly, the bottom scraps collected on the same sampling date had high levels of $N$. apis suggesting that the spores may have been released within the hive, or that they had not yet been released from the midgut epithelial cell at the time of sampling.

Correlative relationships were established for $N$. apis in bottom scraps and those found within the intestines of worker honeybees strongly, 


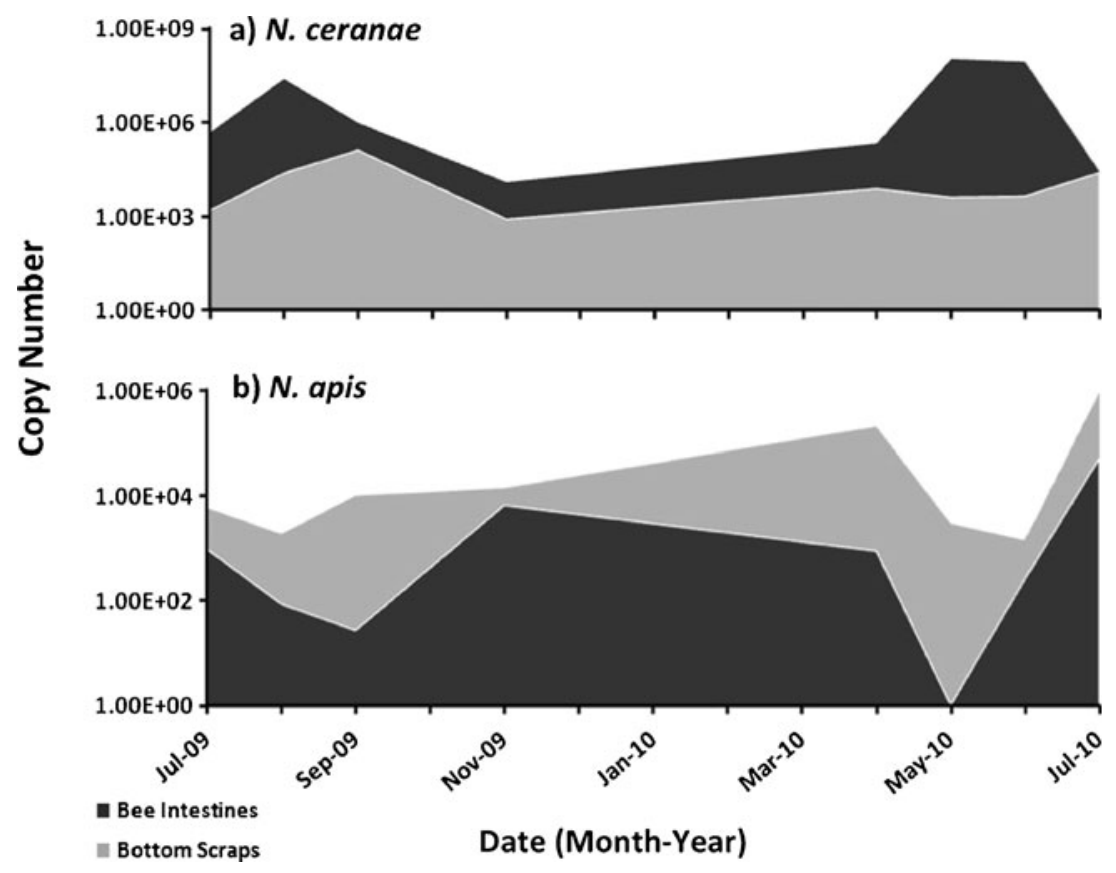

Figure 4. Average monthly distribution of N. ceranae (a) and N. apis (b) in bottom scraps and bee intestines from July 2009 to July 2010. Copy numbers are represented as the average copy number per bee for bee intestines or per $100 \mathrm{mg}$ for bottom scraps for all four hives for each time point. Bee intestines (dark grey), bottom scraps (light grey).

suggesting that bottom scraps have potential to become a useful indicator of the presence and possibly the extent of the disease in the colony and may be extended to honeybees diseases and other important insect diseases that are transmitted via faecal-oral route, such as the infective Triatoma virus, the causal agent of Chagas disease that is transmitted in faecal matter of Triatoma infestans (Muscio et al. 2000). The differences observed in nucleic acid levels in bottom scraps and intestines may be explained by the epidemiology and pathology of both Nosema species. N. apis is known to cause dysentery, increasing the likelihood of defecation within the hive, while $N$. ceranae shows minimal amounts of dysentery (Higes et al. 2008b; Fries 2010) which may account for the differences observed in the correlation values.

This study supports the concept that hives should be cleaned on a regular basis to minimize the amount of infectious diseases present in the hive. Additionally, screen bottom boards may help in reducing the spread of Nosema species infection source by reducing the contact of bees with hive debris. Hive maintenance has proven to be an important factor in hive health, as recent studies have demonstrated that increased hive maintenance and management help to reduce the amount of hive losses during the winter (CAPA 2010). Bottom board debris can be kept to test for the presence of Nosemosis, and may prove to be a reliable sampling method for other honeybee diseases. Molecular diagnostic tools such as qPCR are more sensitive than conventional PCR methods, are reliable and reproducible, and are applicable to many different sampling techniques. The study has demonstrated that Nosema species can be detected and reliably quantified in bottom scraps and frass of bee hives using qPCR diagnostic assays and additionally techniques that are not detrimental to the hive health, are faster, and are as reliable as sampling bees from within the colony when combined with qPCR diagnostic tests. 


\section{ACKNOWLEDGMENTS}

We would like to thank Emile Houle and the members of the CRSAD team for providing the samples for this project, and Huilan Chen for her technical assistance. This work was supported by the Ministère d'Agriculture, Pêcheries et Alimentation de Québec (MAPAQ) and in part by the Natural Sciences and Engineering Research Council (NSERC).

Détection de Nosema apis et $N$. ceranae dans les débris et les déjections d'abeilles tombés dans le fond de ruches naturellement infectées

Microsporidie / Nosema / indicateur de maladie / PCR quantitative / Apis mellifera / méthode de contrôle / santé de la ruche

Nachweis von Nosema apis und $N$. ceranae im Gemüll und Exkremente von natürlich befallenen Bienenvölkern

Nosema ceranae / Nosema apis / Diagnose / Gemüll / Exkremente

\section{REFERENCES}

Bailey, L. (1955) The epidemiology and control of Nosema disease of the honey bee. Ann. Appl. Biol. 43, 379-389

Bailey, L. (1968) Honey bee pathology. Annu. Rev. Entomol. 13, 191-212

CAPA, CAPA Statement on honey bee losses in Canada, 2010. Canadian Association of Professional Apiculturalists

Chen, Y., Evans, J., Zhou, L., Boncristiani, H., Kimura, K., Xiao, T., Litkowski, A., Pettis, J. (2009) Asymmetrical coexistence of Nosema ceranae and Nosema apis in honey bees. J. Invertebr. Pathol. 101, 204-209

Chen, Y., Huang, Z. (2010) Nosema ceranae, a newly identified pathogen of Apis mellifera in the USA and Asia. Apidologie 41, 364-374
Copley, T., Jabaji, S. (2012) Honeybee glands as possible infection reservoirs of Nosema ceranae and Nosema apis in naturally infected forager bees. J. Appl. Microbio. 111, 15-24

Fries, I. (2010) Nosema ceranae in European honey bees (Apis mellifera). J. Invertebr. Pathol. 103, S73-S79

Fries, I., Camazine, S. (2001) Implications of horizontal and vertical pathogen transmission for honey bee epidemiology. Apidologie. 32, 199-214

Fries, I., Martin, R., Meana, A., Garcia-Palencia, P., Higes, M. (2006) Natural infections of Nosema ceranae in European honey bees. J. Apic. Res. 45, 230-233

Higes, M., Martín-Hernández, R., Garrido-Bailon, E., García-Palencia, P., Meana, A. (2008a) Detection of infective Nosema ceranae (Microsporidia) spores in corbicular pollen of forager honeybees. J. Invertebr. Pathol. 97, 76-78

Higes, M., Martín Hernández, R., Botías, C., Bailón, E., González Porto, A., Barrios, L., Del Nozal, M., Bernal, J., Jiménez, J., Palencia, P. (2008b) How natural infection by Nosema ceranae causes honeybee colony collapse. Environ. Microbiol. 10, 2659-2669

Higes, M., Martín, R., Meana, A. (2006) Nosema ceranae, a new microsporidian parasite in honeybees in Europe. J. Invertebr. Pathol. 92, 93-95

Klee, J., Besana, A., Genersch, E., Gisder, S., Nanetti, A., Tam, D., Chinh, T., Puerta, F., Ruz, J., Kryger, P. (2007) Widespread dispersal of the microsporidian Nosema ceranae, an emergent pathogen of the western honey bee, Apis mellifera. J. Invertebr. Pathol. 96, 1-10

Martín-Hernández, R., Meana, A., Prieto, L., Salvador, A., Garrido-Bailon, E., Higes, M. (2007) Outcome of colonization of Apis mellifera by Nosema ceranae. Appl. Environ. Microbiol. 73, 6331-6338

Muscio, O., Bonder, M.A., La Torre, J.L., Scodeller, E.A. (2000) Horizontal transmission of Triatoma virus through the fecal-oral route in Triatoma infestans (Hemiptera: Triatomidae). J. Med. Entomol. 37, 271275

Traver, B.E., Fell, R.D. (2011) Prevalence and infection intensity of Nosema in honey bee (Apis mellifera L.) colonies in Virginia. J. Invertebr. Pathol.. doi:10.1016/ j.jip.2011.02.003 